FACTA UNIVERSITATIS

Series: Working and Living Environmental Protection Vol. 18, No 2, 2021, pp. 87 - 102

https://doi.org/10.22190/FUWLEP2102087P

Original Scientific Paper

\title{
NUMERICAL INVESTIGATION OF A SOLAR-DRIVEN ORGANIC RANKINE CYCLE COUPLED TO A GEOTHERMAL FIELD
}

\author{
UDC 620.91:550.36
}

\author{
Saša Pavlović1, Evangelos Bellos ${ }^{2}$, Milan Grozdanović1 \\ ${ }^{1}$ Department for Energy and Process Engineering, Faculty of Mechanical Engineering, \\ University in Niš, Serbia \\ ${ }^{2}$ School of Mechanical Engineering, National Technical University of Athens, \\ Athens, Greece
}

\begin{abstract}
The objective of this work is to investigate a solar-driven Organic Rankine Cycle (ORC) for power production with a geothermal well as the heat sink for the ORC condenser. The examined unit combines the exploitation of two renewable energy sources. Solar irradiation is exploited by using solar dish concentrators with spiral absorbers, while the geothermal field includes vertical boreholes with U-tubes. The system is investigated parametrically with a developed model in Engineering Equation Solver, and the examined parameters are the solar beam irradiation level, the total thermal conductivity of the ORC condenser, the borehole length, the number of the boreholes and the mean ground temperature. For the default scenario, it is found that system electrical efficiency is $21.45 \%$, the ORC's thermodynamic efficiency is $35.99 \%$, and the solar field efficiency is $61.30 \%$. Moreover, it is found that the examined system is $5.7 \%$ more efficient than a conventional air-cooled condenser system.
\end{abstract}

Key words: Solar dish concentrator, Organic Rankine Cycle, Geothermal energy, Parametric analysis, Concentrating Solar Power

\section{INTRODUCTION}

The use of renewable energy sources is a vital way in order to face critical problems like fossil fuel depletion, global warming and increasing energy needs [1-3]. Solar energy, geothermal energy, biomass and wind energy are the most common renewable energy sources for electricity production. Usually, more than one renewable energy source can be

Received July 25, 2021 / Accepted October 5, 2021

Corresponding author: Saša Pavlović

University of Niš, Faculty of Mechanical Engineering, Aleksandra Medvedeva 14, 18000 Niš, Serbia

E-mail: saledoca@gmail.com

ㄷ 2021 by University of Niš, Serbia | Creative Commons Licence: CC BY-NC-ND 
combined (e.g., solar and biomass [4]) for achieving sustainable configurations with a stable operating profile. Usually, solar energy can be exploited by solar thermal concentrating collectors coupled to thermodynamic cycles for producing electricity [5]. The use of compound parabolic concentrators [6], parabolic trough collectors [7] and solar dish concentrators [8] can be applied in solar-driven power systems.

There are many studies on solar-driven power systems in the literature, and various ideas can be studied. Especially, there is much interest in the use of solar dish concentrators as the solar thermal technology because this is a focal point configuration that can achieve a high concentration ratio and help high-temperature levels be easily developed.

Loni et al. [9] performed an energetic and exergetic analysis of a solar-driven organic Rankine cycle (ORC) for power production. The examined collector had a cubical cavity receiver and a paraboloid shape concentrator. They studied the effect of the cavity receiver design, and they concluded that a smaller inner tube's diameter enhances the efficiency. Moreover, Loni et al. [10] examined the same idea but with a cubical cavity design. They concluded that the global optimal design is the one with the cavity depth to be equal to the cavity aperture diameter. In this direction, the cubical design was studied furthermore by Loni et al. [11], and it was found that the maximum system efficiency is about $38 \%$ which is a satisfying value.

The next part of the literature regards studies with solar dish concentrators coupled to polygeneration units that incorporate ORC. Ozturk et al. [12] investigated a complex configuration for producing electricity, heating, cooling, hydrogen and oxygen. According to the final results, it is found that the energetic and exergetic efficiencies were $52.7 \%$ and $57.4 \%$, respectively. In another investigation, Moradi and Mehrpooya [13] worked on the optimization of a trigeneration system that includes a fuel cell and solar collectors. They found that the electric and the total efficiencies are $48.7 \%$ and $79.5 \%$, respectively. Yilmaz et al. [14] studied a solar-driven polygeneration unit for producing cooling, heating, electricity, hydrogen, fresh water and drying. The energy efficiency was found at $48.2 \%$, while the exergy efficiency was at $43.8 \%$.

The aforementioned literature review indicates that there is much interest in the use of solar dish concentrators coupled to ORC for electricity production or combinations of various useful outputs, including electricity. In this direction, this work studies a configuration with four solar dish concentrators coupled to an insulated storage tank that feeds an ORC. The novelty of this work is the use of a geothermal field as the heat sink that the ORC rejects heat. This technique aids in reducing the condensation temperature of the ORC, so the thermodynamic efficiency of the cycle is increased. This work is a parametric study of the previous system, and also the enhancement compared to a conventional system without a geothermal heat sink is studied. The simulation was conducted by a detailed developed model in Engineering Equation Solver [15].

\section{MATERIAL AND METHODS}

\subsection{The configuration of the studied unit}

In this work, a power system with solar energy is studied. The examined unit is depicted in figure 1. Obviously, there are four solar dish collectors with a total aperture of $40 \mathrm{~m}^{2}$ used to feed a tank of $0.5 \mathrm{~m}^{3}$ storage volume. The solar field and the tank operate with thermal oil. The storage tank is an insulated tank that feeds the heat recovery system (HRA) of an ORC 
that operates with toluene. The ORC rejects heat from the condenser to a geothermal field with vertical boreholes. The examined solar dish concentrator has a spiral receiver inside a cavity, and its experimental analysis is given in Ref. [16]. The ORC cycle uses toluene as the proper working fluids, according to Ref. [17].

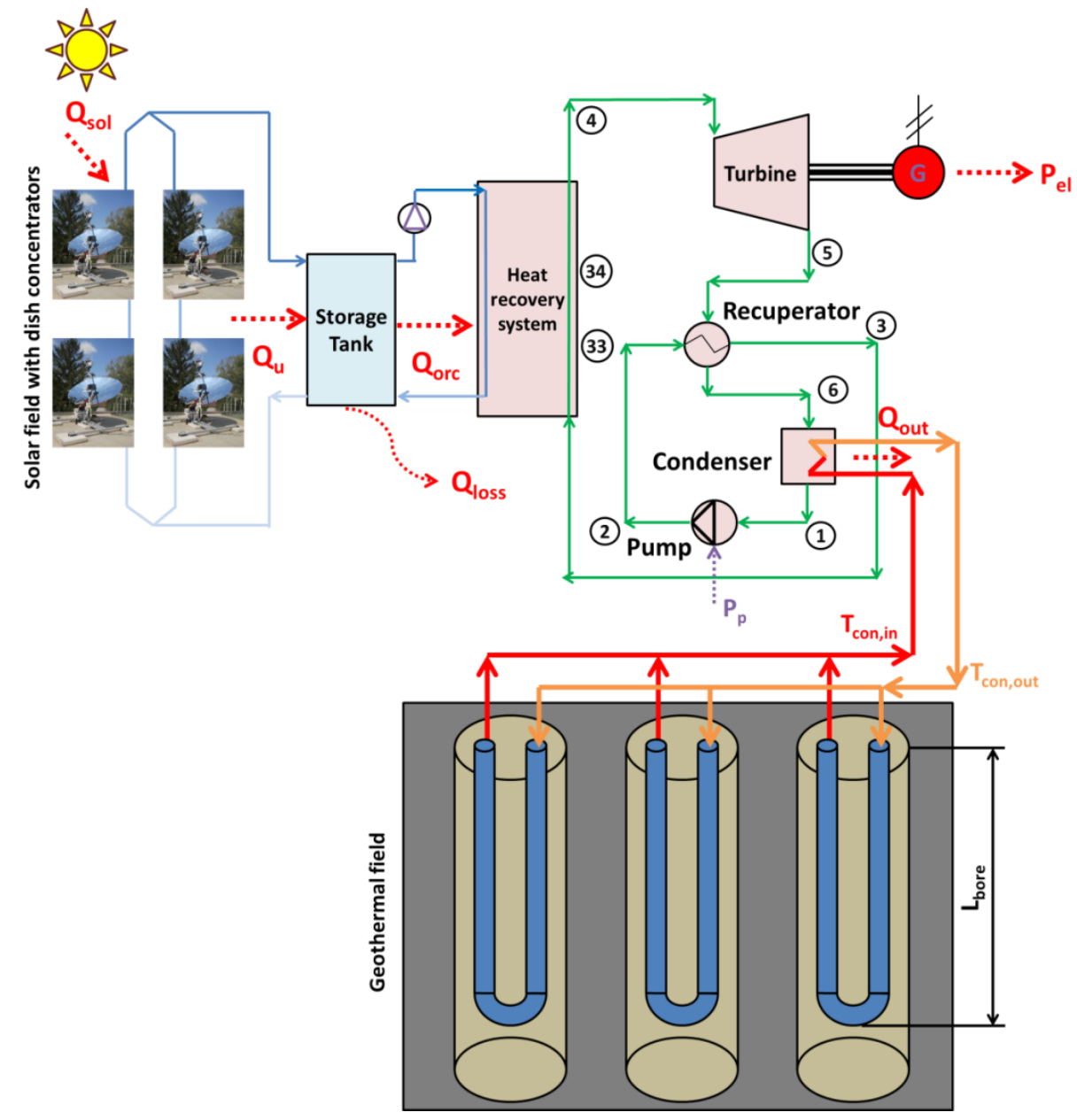

Fig. 1 Depiction of the studied solar-driven ORC with geothermal heat sink

\subsection{Basic mathematical modeling}

\subsubsection{Solar field modeling}

The next formula gives the solar thermal efficiency of the solar dish $\left(\eta_{t h}\right)$ according to the results of References [18-19]:

$$
\eta_{c o l}=0.68199-0.1946 \cdot \frac{T_{c o l, f m}-T_{a m}}{G_{b}}-0.00056 \cdot \frac{\left(T_{c o l, f m}-T_{a m}\right)^{2}}{G_{b}}
$$


Moreover, the collector thermal efficiency $\left(\eta_{t h}\right)$ is the ratio of the useful heat $\left(Q_{u}\right)$ to the solar input $\left(Q_{s o l}\right)$ :

$$
\eta_{c o l}=\frac{Q_{u}}{Q_{s o l}}=\frac{m_{c o l} \cdot c_{p, o i l} \cdot\left(T_{c o l, o u t}-T_{c o l, \text { in }}\right)}{A_{c o l} \cdot G_{b}}
$$

It has to be said that the mean fluid temperature in the collector $\left(T_{c o l, f m}\right)$ is the average of the inlet $\left(T_{\text {col,in }}\right)$ and the outlet temperature $\left(T_{\text {col,out }}\right)$.

The general energy balance in the storage tank is given as below:

$$
Q_{s t}=Q_{u}-Q_{\text {loss }}-Q_{\text {orc }}
$$

The stored energy $\left(Q_{s t}\right)$ is found by reducing the tank losses $\left(Q_{\text {loss }}\right)$ and the heat input in the heat recovery system of the ORC $\left(Q_{o r c}\right)$ from the useful heat production $\left(Q_{u}\right)$.

\subsubsection{Organic Rankine cycle modeling}

The basic equations of the ORC modeling are given below. More details can be found in Ref. [20]. The energy balance in the heat recovery system can be found with the respective energy balance in the HRS:

$$
Q_{\text {orc }}=m_{\text {orc }} \cdot\left(h_{4}-h_{3}\right)
$$

The net electricity production $\left(P_{e l}\right)$ is found as below:

$$
P_{e l}=\eta_{m g} \cdot P_{t u r}-P_{p}
$$

The turbine production $\left(P_{t u r}\right)$ is calculated as:

$$
P_{\text {tur }}=m_{\text {orc }} \cdot\left(h_{4}-h_{5}\right)
$$

The electricity consumption in the pump $\left(P_{p}\right)$ is calculated as:

$$
P_{p}=\frac{m_{\text {orc }} \cdot\left(h_{2}-h_{1}\right)}{\eta_{\text {motor }}}
$$

The heat rejection in the condenser $\left(Q_{\text {out }}\right)$ is calculated as below:

$$
Q_{\text {out }}=m_{\text {orc }} \cdot\left(h_{6}-h_{1}\right)
$$

It also has to be stated that the state point (1) is assumed to be saturated liquid of low pressure, the pump is modeled with an overall motor efficiency of $70 \%$, the isentropic efficiency of the turbine is $85 \%$, and the process in the throttling vale is adiabatic and consequently isenthalpic. The temperature difference in the recuperator is selected at 10 $\mathrm{K}$, as well as the pinch point in the HRS is also $10 \mathrm{~K}$.

\subsubsection{Geothermal field modeling}

The geothermal field is modeled using the thermal resistance modeling described according to ASHRAE [21]. Firstly, the heat transfer modeling in the condenser is described as below: 


$$
\begin{gathered}
Q_{\text {out }}=m_{g f} \cdot c_{p, g f} \cdot\left(T_{c o n, \text { out }}-T_{\text {con, in }}\right)=\rho_{g f} \cdot V_{g f} \cdot c_{p, g f} \cdot\left(T_{c o n, o u t}-T_{c o n, i n}\right) \\
Q_{\text {out }}=(U A)_{c o n} \cdot \Delta \mathrm{T}_{l m}=(U A)_{c o n} \cdot \frac{T_{c o n, i n}-T_{c o n, o u t}}{\ln \left[\frac{T_{c o n}-T_{c o n, o u t}}{T_{c o n}-T_{c o n, i n}}\right]}
\end{gathered}
$$

Moreover, it has to be said that the mass flow rate in every borehole $\left(m_{g f, 0}\right)$ is found by dividing the total mass flow rate to the condenser $\left(m_{g f}\right)$ by the total boreholes number $(N)$. Furthermore, the mean geothermal fluid temperature in the condenser $\left(T_{c o n, f n}\right)$ is given as the mean value of $\left(T_{\text {col, in }}\right)$ and $\left(T_{\text {col,out }}\right)$.

The heat rejection from the condenser to the geothermal field is calculated according to the following formula [21]:

$$
Q_{o u t}=N \cdot \frac{L_{b o r e} \cdot\left(T_{c o n, f m}-T_{g}\right)}{R_{o v}}
$$

The overall thermal resistance per length $\left(R_{o v}\right)$ is found as the summary of other thermal resistances per length by following the ASHRAE methodology [21]. More specifically, the overall resistance $\left(R_{o v}\right)$ is the sum of the heat exchanger thermal resistance $\left(R_{p}\right)$ and thermal resistance of the grout $\left(R_{g r t}\right)$. This modeling assumes that there are not many fluctuations in the operational profile.

$$
R_{o v}=R_{p}+R_{g r t}
$$

The heat exchanger (U-tube) thermal resistance is normalized to the borehole length $\left(L_{b o r e}\right)$, and so, for a single (U-tube), the heat exchanger thermal resistance is given as:

$$
R_{p}=\frac{R_{\text {film }}+R_{\text {tube }}}{2}
$$

The thermal resistance between the geothermal fluid and the $\mathrm{U}$-tube $\left(\mathrm{R}_{\mathrm{film}}\right)$ is calculated as:

$$
R_{f i l m}=\frac{1}{\pi \cdot d_{i n} \cdot h_{g f}}
$$

The U-tube thermal resistance $\left(R_{\text {tube }}\right)$ is calculated as below:

$$
R_{\text {tube }}=\frac{\ln \left[\frac{d_{\text {out }}}{d_{\text {in }}}\right]}{2 \cdot \pi \cdot k_{\text {tube }}}
$$

The grout thermal resistance $\left(R_{g r t}\right)$ is the thermal resistance of the filling material in the borehole area. For a borehole diameter of $\left(d_{p}\right)$, it can be written [21]:

$$
R_{g r t}=\left(k_{g r t} \cdot b_{0} \cdot\left[\frac{d_{p}}{d_{\text {out }}}\right]^{b 1}\right)^{-1}
$$


The coefficients of the previous formula are selected at $b_{0}=21.91$ and $b_{1}=-0.3797$ [21]

The Nusselt number $(\mathrm{Nu})$ is used to express the heat transfer coefficient of the fluid $\left(h_{g f}\right)$.

$$
N u=\frac{h_{g f} \cdot d_{i n}}{k_{g f}}
$$

Also, the Nusselt number $(\mathrm{Nu})$ for turbulent flow is found with the Colburn model [22]:

$$
N u=0.023 \cdot \operatorname{Re}^{0.8} \cdot \operatorname{Pr}^{1 / 3}
$$

The Reynolds number $(R e)$ and the Prandtl number $(P r)$ of the fluid are used in the equation above.

\subsection{Simulation methodology}

In this work, a model is developed in Engineering Equation Solver [15] according to the equations of section 2.2. The present work assumes a default scenario, and then a parametric work is performed by changing only one parameter in every case. Table 1 includes the main data of the present work and Table 2 includes the examined parameters, their default values and the examined range of every parameter.

Table 1 Data of the present analysis in the default scenario

\begin{tabular}{lcc}
\hline Parameter & Symbol & Value \\
\hline Ambient temperature & $\mathrm{T}_{\mathrm{am}}$ & $25^{\circ} \mathrm{C}$ \\
\hline Turbine isentropic efficiency & $\eta_{\mathrm{tur}}$ & $85 \%$ \\
\hline Motor efficiency of the pump & $\eta_{\text {motor }}$ & $70 \%$ \\
\hline Temperature difference in the recuperator & $\Delta \mathrm{T}_{\mathrm{rec}}$ & $10 \mathrm{~K}$ \\
\hline Pinch Point in the heat recovery system & $\mathrm{PP}$ & $10 \mathrm{~K}$ \\
\hline Superheating in the turbine inlet & $\Delta \mathrm{T}_{\mathrm{sh}}$ & $30 \mathrm{~K}$ \\
\hline Turbine inlet pressure & $\mathrm{p}_{\mathrm{high}}$ & $37.14 \mathrm{bar}$ \\
\hline Solar field area (4 modules) & $\mathrm{A}_{\mathrm{col}}$ & $40 \mathrm{~m}^{2}$ \\
\hline Storage tank volume & $\mathrm{V}_{\mathrm{T}}$ & $0.5 \mathrm{~m}^{3}$ \\
\hline Thermal losses coefficient of the tank & $\mathrm{U}_{\mathrm{T}}$ & $0.5 \mathrm{~W} / \mathrm{m}^{2} \mathrm{~K}$ \\
\hline Volumetric flow rate in the evaporator & $\mathrm{V}_{\mathrm{gf}}$ & $5 \mathrm{~L} / \mathrm{s}$ \\
\hline Thermal conductivity of the grout & $\mathrm{k}_{\mathrm{grt}}$ & $2.1 \mathrm{~W} / \mathrm{mK}$ \\
\hline Thermal conductivity of the U-tube & $\mathrm{k}_{\text {tube }}$ & $0.45 \mathrm{~W} / \mathrm{mK}$ \\
\hline Inner diameter of the U-tube & $\mathrm{d}_{\text {in }}$ & $0.025 \mathrm{~m}$ \\
\hline Outer diameter of the U-tube & $\mathrm{d}_{\mathrm{out}}$ & $0.032 \mathrm{~m}$ \\
\hline Borehole diameter & $\mathrm{d}_{\mathrm{p}}$ & $0.125 \mathrm{~m}$ \\
\hline
\end{tabular}

Table 2 Values of the parametric analysis

\begin{tabular}{lccc}
\hline Parameter & Symbol & Default value & Range \\
\hline Solar direct beam irradiation & $\mathrm{G}_{\mathrm{b}}$ & $900 \mathrm{~W} / \mathrm{m}^{2}$ & {$[300-900] \mathrm{W} / \mathrm{m}^{2}$} \\
Thermal transmittance in the condenser & $(\mathrm{UA})_{\mathrm{con}}$ & $5 \mathrm{~kW} / \mathrm{K}$ & {$[1-8] \mathrm{kW} / \mathrm{K}$} \\
Ground temperature & $\mathrm{T}_{\mathrm{g}}$ & $18^{\circ} \mathrm{C}$ & {$[15-22]^{\circ} \mathrm{C}$} \\
Number of boreholes & $\mathrm{N}$ & 5 & {$[1-8]$} \\
Bore length & Lbore & $50 \mathrm{~m}$ & {$[10-80] \mathrm{m}$} \\
\hline
\end{tabular}




\section{RESULTS AND DISCUSSION}

\subsection{Preliminary analysis}

In the first part of the results section, the analysis of the default scenario is presented. The values of the examined parameters have their default values, according to Table 2 in this scenario. The results of this investigation are included in Table 3. It is found that the produced electricity is $7.723 \mathrm{~kW}$ with a solar input of $36 \mathrm{~kW}$. The system electrical efficiency is found at $21.45 \%$, the ORC thermodynamic efficiency at $35.99 \%$ and the solar collector thermal efficiency a $61.30 \%$. Moreover, it has to be said that the overall resistance per length in the geothermal heat exchanger is $0.08112 \mathrm{mK} / \mathrm{W}$ and the geothermal fluid heat transfer coefficient is $6278 \mathrm{~W} / \mathrm{m}^{2} \mathrm{~K}$. The condenser temperature in this design is $25.1^{\circ} \mathrm{C}$, with the ground mean temperature at $18^{\circ} \mathrm{C}$. So, it means that there is a relatively low condenser temperature with the geothermal energy exploitation.

Table 3 Main results in the default scenario

\begin{tabular}{lcc}
\hline Parameter & Symbol & Default value \\
\hline Solar energy & $\mathrm{Q}_{\text {sol }}$ & $36 \mathrm{~kW}$ \\
Useful heat production from the solar dishes & $\mathrm{Q}_{\mathrm{u}}$ & $22.07 \mathrm{~kW}$ \\
Heat input in the ORC & $\mathrm{Q}_{\text {orc }}$ & $21.46 \mathrm{~kW}$ \\
Heat rejection to the geothermal field & $\mathrm{Q}_{\text {out }}$ & $13.55 \mathrm{~kW}$ \\
Net electricity production & $\mathrm{P}_{\mathrm{el}}$ & $7.723 \mathrm{~kW}$ \\
Solar collector efficiency & $\eta_{\text {col }}$ & $61.30 \%$ \\
ORC efficiency & $\eta_{\text {orc }}$ & $35.99 \%$ \\
System electrical efficiency & $\eta_{\mathrm{el}}$ & $21.45 \%$ \\
Overall Resistance & $\mathrm{R}_{\mathrm{ov}}$ & $0.08112 \mathrm{mK} / \mathrm{W}$ \\
Condenser temperature & $\mathrm{T}_{\mathrm{con}}$ & $25.1^{\circ} \mathrm{C}$ \\
Fluid inlet temperature in the condenser & $\mathrm{T}_{\mathrm{con}, \text { in }}$ & $22.1^{\circ} \mathrm{C}$ \\
Fluid outlet temperature in the condenser & $\mathrm{T}_{\text {con,out }}$ & $22.7^{\circ} \mathrm{C}$ \\
Fluid heat transfer coefficient & $\mathrm{h}_{\mathrm{gf}}$ & $6278 \mathrm{~W} / \mathrm{m}^{2} \mathrm{~K}$ \\
\hline
\end{tabular}

At this point, it is important to perform a simple comparison with the conventional system with an air-cooled condenser. In this case, the condenser temperature is assumed to be at $40^{\circ} \mathrm{C}$, which is a typical value for locations that utilize solar concentrating power. In this case, the electricity production is $7.308 \mathrm{~kW}$, the system electrical efficiency is $20.30 \%$, the thermodynamic efficiency of the ORC is $34.05 \%$, and the solar field efficiency is $61.30 \%$. So, it can be said that the geothermal-based system presents about $5.7 \%$ higher performance compared to the conventional design. This is an important enhancement that indicates that the proposed configuration is an efficient one. Practically, the difference of the condenser temperature from $40{ }^{\circ} \mathrm{C}$ in the conventional system to $25.01^{\circ} \mathrm{C}$ in the geothermal system is the key factor in the performance enhancement due to the higher ORC thermodynamic efficiency with lower condenser temperature.

\subsection{Parametric investigation}

The next part of this work is the parametric investigation of the examined system. Five different parameters are investigated, and in every case, the system efficiencies and other critical parameters are presented. 
Figures 2 and 3 show the impact of the solar beam irradiation level on the system performance. It is important to state that solar concentrating technologies exploit only beam irradiation. Also, the examined solar dish has a two-axis tracking system. So the incident angle modifier is practically $100 \%$ during the operation because the sun rays are vertical to the collector aperture. Figure 2 shows that higher solar beam irradiation leads

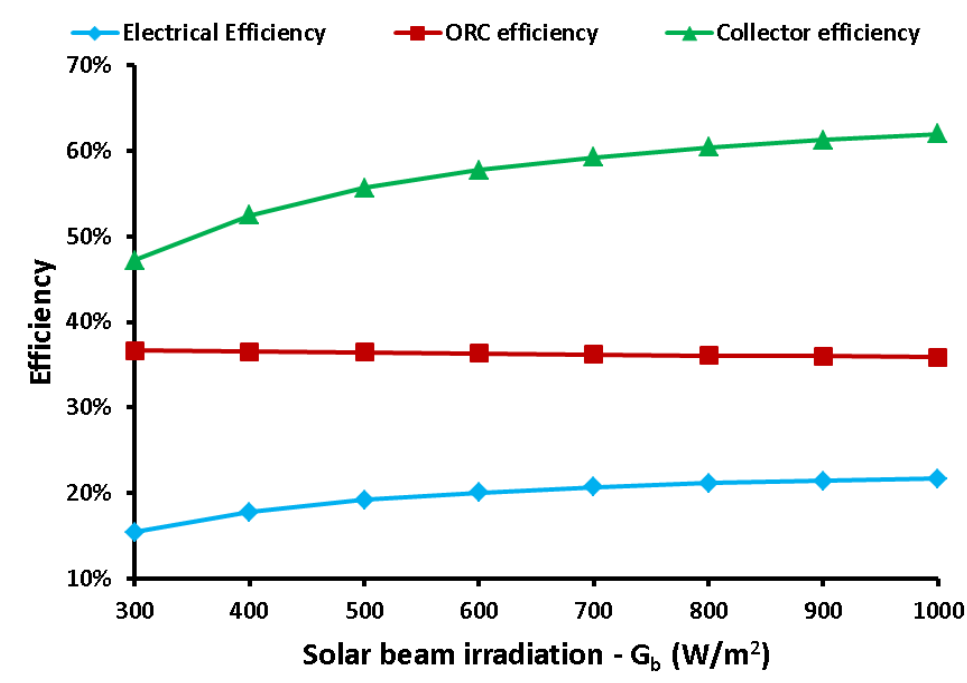

Fig. 2 Efficiency values for different solar beam irradiation levels

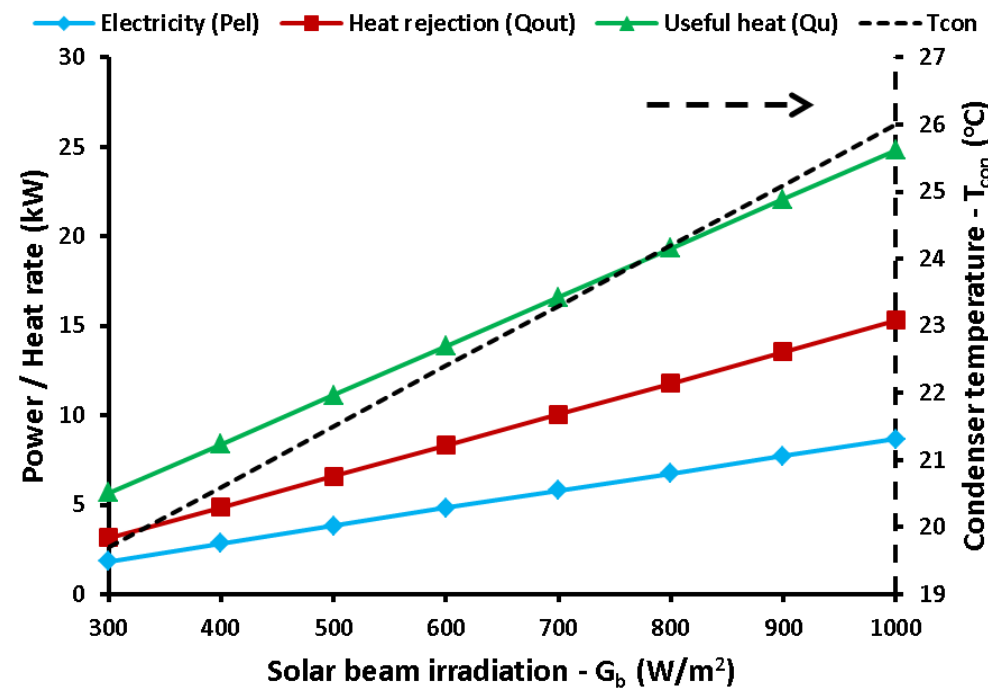

Fig. 3 Electricity rate, useful heat rate, heat rejection rate and condenser temperature for different solar beam irradiation levels 
to higher collector efficiency, while the ORC efficiency presents a very small reduction. The result is the increase of the system's electrical efficiency with the increase of solar irradiation. The reason for a small reduction in the ORC efficiency is the increase of the condenser temperature for higher temperatures, as Figure 3 indicates. Practically, the finite thermal capacitance of the geothermal field makes the condenser temperature go to higher values to transfer higher heat rates from the condenser to the ground when there is more solar potential. In any case, the ORC efficiency decrease ranges from $36.68 \%$ to $35.87 \%$, which is not a high variance. On the other hand, the electrical efficiency is enhanced from $15.45 \%$ to $21.70 \%$; a variation that indicates high significance between the power production and the solar irradiation level. This fact is justified by the increasing electrical production rate with the solar irradiation increase, according to Figure 3. It has to be emphasized that the condenser temperature range from $19.7^{\circ} \mathrm{C}$ to $26.0^{\circ} \mathrm{C}$ when the solar irradiation varies from $300 \mathrm{~W} / \mathrm{m}^{2}$ to $1000 \mathrm{~W} / \mathrm{m}^{2}$.

The next examined parameter is the condenser total thermal transmittance, whereas the results are given in Figures 4 and 5. It can be said that this parameter has no significant impact on the results. Higher values of this parameter enhance the ORC efficiency and the system electrical efficiency but in a small percentage. More specifically, the system efficiency is enhanced from $20.58 \%$ to $21.53 \%$ when the condenser's total thermal transmittance is ranged from $1 \mathrm{~kW} / \mathrm{K}$ to $8 \mathrm{~kW} / \mathrm{K}$, according to Figure 4 . The reason for the enhancement is the decrease of the condenser temperature from $36.3^{\circ} \mathrm{C}$ to $24.1^{\circ} \mathrm{C}$, which enhances the ORC thermodynamic efficiency and consequently the system's electrical efficiency. Also, it is useful to state that the increase of the condenser total thermal transmittance leads to higher electrical production and lower heat rejection to the geothermal field. These quantities have an approximately constant sum due to the constant collector efficiency. Therefore, the results are justified. Lastly, it can be said that a thermal transmittance of at least $4 \mathrm{~kW} / \mathrm{K}$ leads to satisfying results according to the curves of Figures 4 and 5.

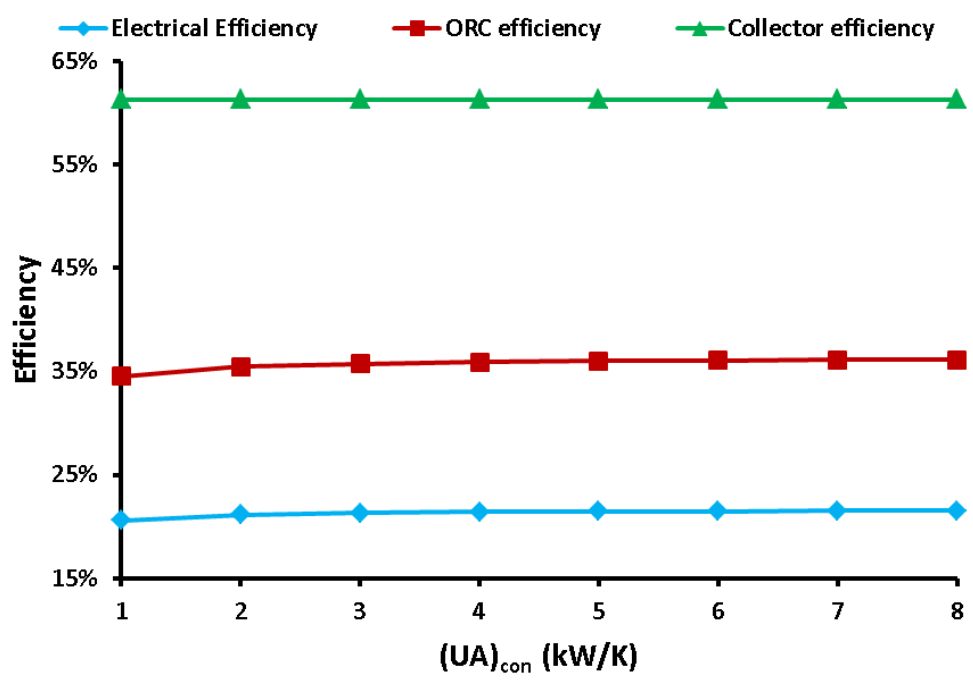

Fig. 4 Efficiency values for different condenser total thermal transmittance values 


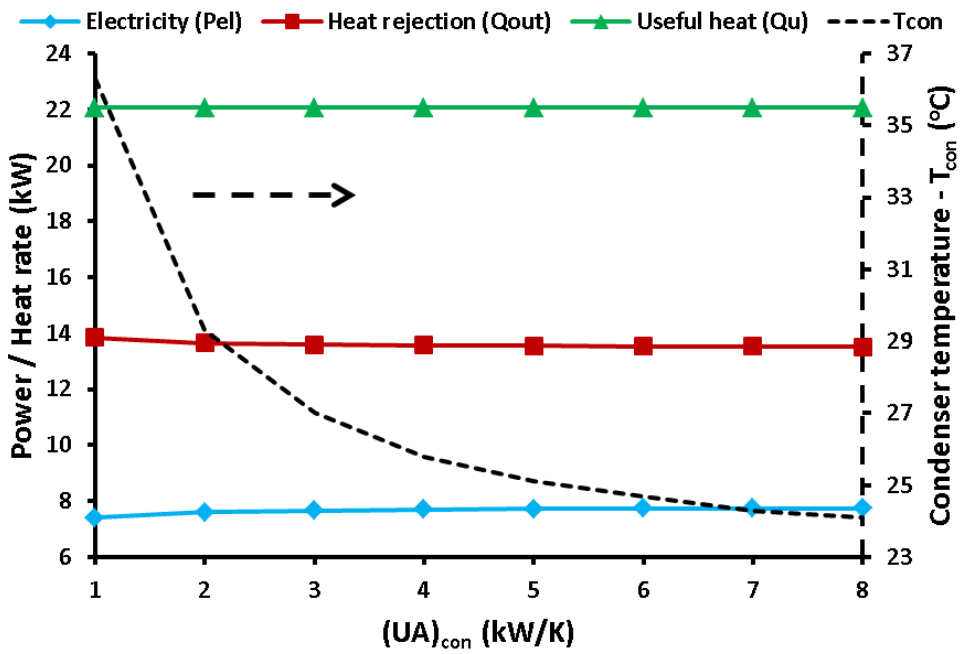

Fig. 5 Electricity rate, useful heat rate, heat rejection rate and condenser temperature for different condenser total thermal transmittance values

Figures 6 and 7 illustrate the influence of the borehole length on the results. It can be said that higher borehole length makes possible the reduction of the condenser temperature, and so the ORC is enhanced. More specifically, the variation of the borehole length from 10 $\mathrm{m}$ to $80 \mathrm{~m}$ makes the ORC thermodynamic efficiency range from $33.59 \%$ to $36.20 \%$ and the electrical efficiency from $20.02 \%$ to $21.58 \%$, according to figure 6 . Figure 7 shows that the variation of the borehole length from $10 \mathrm{~m}$ to $80 \mathrm{~m}$ reduces the condenser temperature from $43.6^{\circ} \mathrm{C}$ to $23.5^{\circ} \mathrm{C}$, which is a huge variation. It can be also noted that a borehole length of at least $40 \mathrm{~m}$ has to be used in order to have a sustainable design.

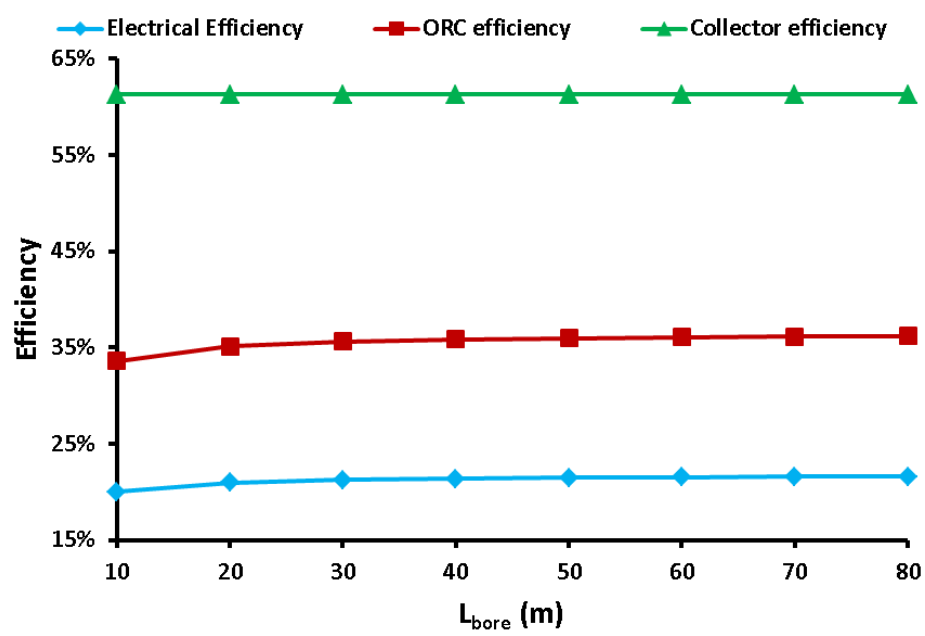

Fig. 6 Efficiency values for different borehole lengths 


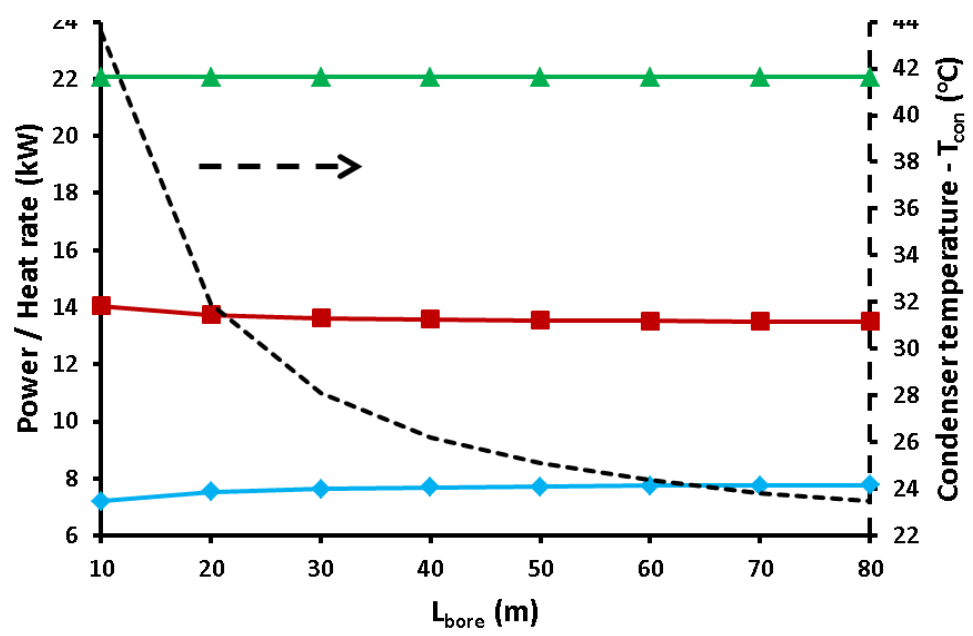

Fig. 7 Electricity rate, useful heat rate, heat rejection rate and condenser temperature for different borehole lengths

Figures 8 and 9 show the influence of the number of boreholes on the system performance. A higher number of boreholes makes the heat transfer from the ORC condenser to the geothermal field easier, and thus the system performance is enhanced. More specifically, figure 8 depicts that the increase of the boreholes from 1 to 8 increases the system electrical efficiency from $20.04 \%$ to $21.58 \%$, while figure 9 indicates that the electricity production is increased from $7.214 \mathrm{~kW}$ to $7.697 \mathrm{~kW}$. The reason for the increase in the electricity with the higher number of boreholes is associated with the reduction of the condenser temperature from $43.4^{\circ} \mathrm{C}$ to $23.5^{\circ} \mathrm{C}$, which is a significant variation. It has to be commented that at least 4 boreholes have to be used in order to have an efficient design.

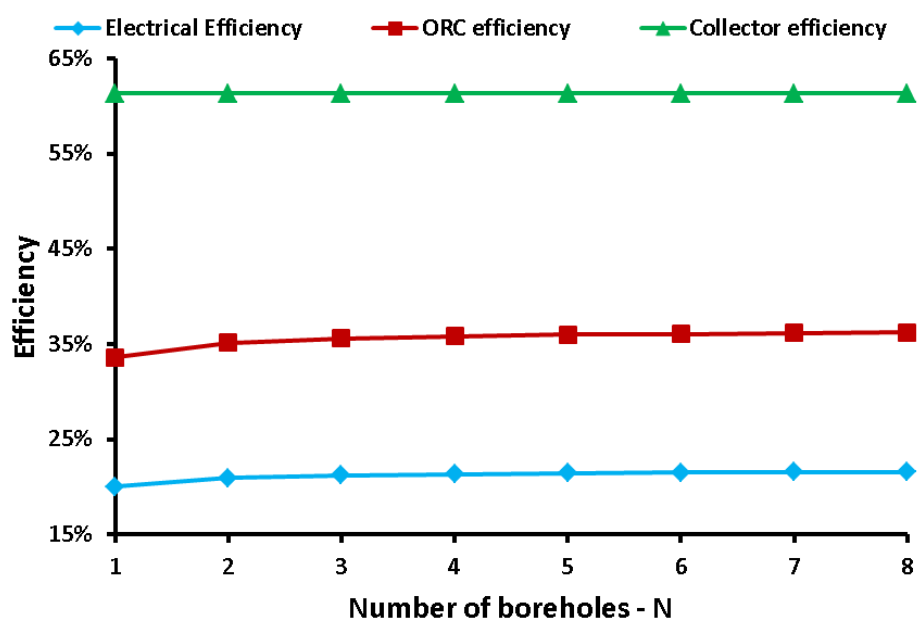

Fig. 8 Efficiency values for different boreholes number 


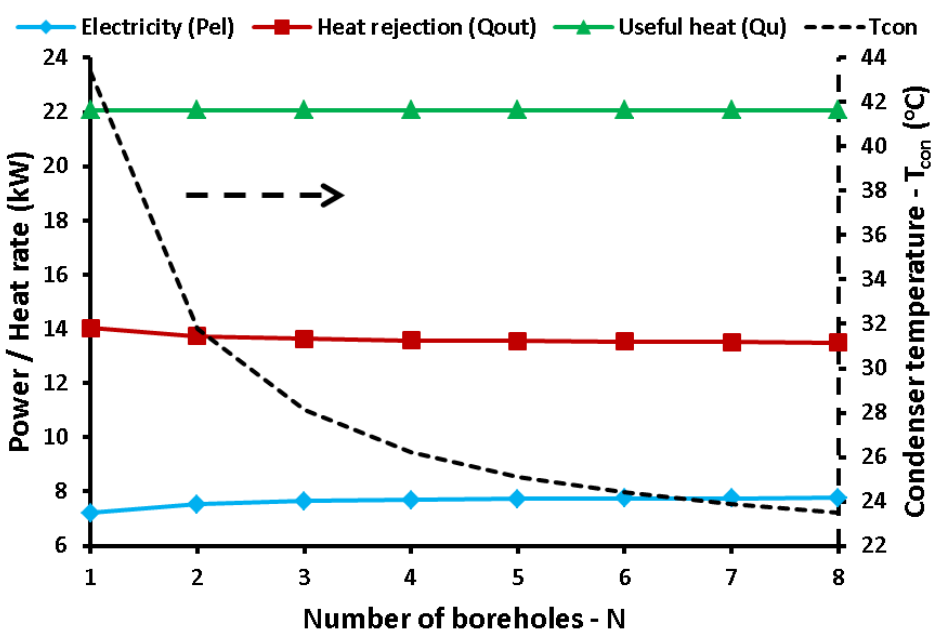

Fig. 9 Electricity rate, useful heat rate, heat rejection rate and condenser temperature for different boreholes number

At the end of the parametric analysis, figures 10 and 11 exhibit the impact of the mean ground temperature on the system performance. The increase of the ground temperature has a negative impact on the system performance, as is obvious from Figure 10. The main reason for this result is the increase of the condenser temperature according to the presented results in Figure 11. More specifically, Figure 10 shows that the electrical efficiency reduces from $21.69 \%$ to $21.14 \%$ when the ground mean temperature varies from $15^{\circ} \mathrm{C}$ to $22^{\circ} \mathrm{C}$. Moreover, Figure 12 indicates that the condenser temperature increases from $22.1^{\circ} \mathrm{C}$ to $29.2^{\circ} \mathrm{C}$ with the increase of the ground temperature. Practically, when the ground temperature increases by $1 \mathrm{~K}$, the condenser temperature also increases by approximately $1 \mathrm{~K}$.

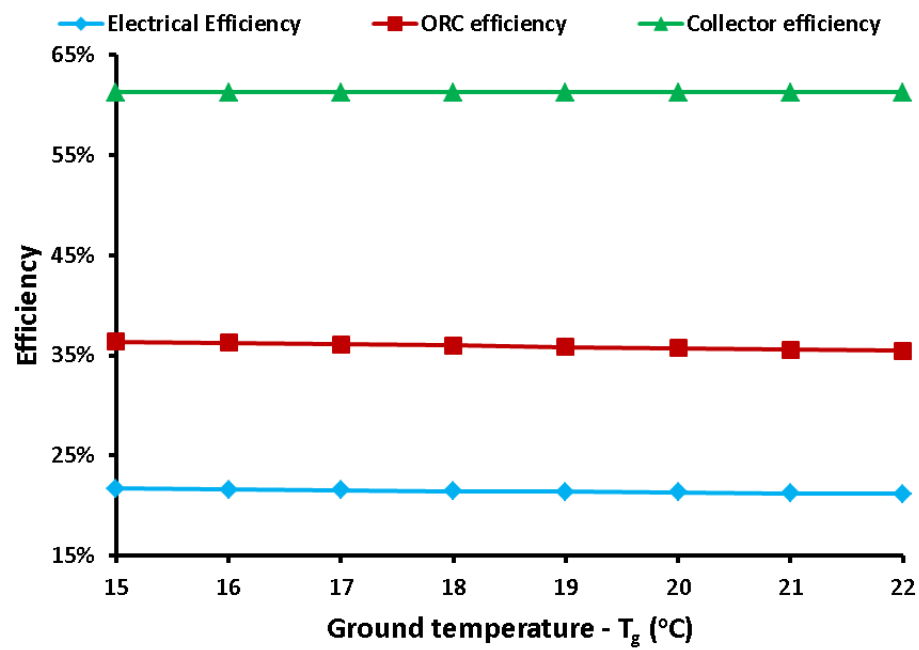

Fig. 10 Efficiency values for different ground mean temperature levels 


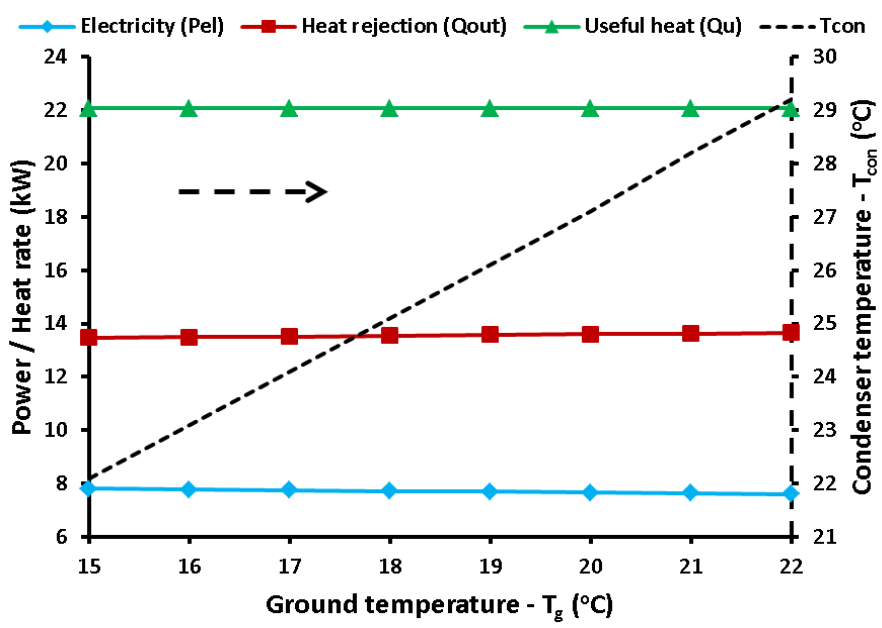

Fig. 11 Electricity rate, useful heat rate, heat rejection rate and condenser temperature for different ground mean temperature levels

Furthermore, it has to be said that the deviations in the system electrical efficiency are not so high. This fact indicates that the ground temperature is not the most important factor in the system's performance. On the other hand, the borehole number, $t$ length and condenser thermal transmittance are more important parameters. Lastly, it has to be said that the solar beam irradiation level is the most critical parameter bout the system performance.

\section{CONCLUSIONS}

The objective of the present investigation is the parametric evaluation of a novel solargeothermal ORC. The examined unit includes a regenerative ORC with toluene as the working fluid fed by solar dish concentrators and rejects heat into a geothermal field. The studied unit is examined with a developed model in Engineering Equation Solver. The most important conclusions of this work are summarized below:

- In the default scenario, it is found that the produced electricity is $7.723 \mathrm{~kW}$ with a solar input of $36 \mathrm{~kW}$. The system electrical efficiency is found at $21.45 \%$, the ORC thermodynamic efficiency $35.99 \%$ and the solar collector thermal efficiency $61.30 \%$.

- It is found that the default scenario leads to $5.7 \%$ higher electricity production compared to the conventional design with an air-cooled condenser.

- In the present system, it was found that there is a need to use at least 4 boreholes, $40 \mathrm{~m}$ in every borehole and thermal transmittance of $4 \mathrm{~kW} / \mathrm{K}$ in order to have an efficient system.

- It has to be stated that the deviations in the system electrical efficiency are not so important when the ground temperature changes. On the other hand, the borehole number, length and condenser thermal transmittance are more important parameters. Lastly, it has to be said that the solar beam irradiation level is the most critical parameter for the overall system performance.

- In the future, the present system can be examined on dynamic conditions every year. Also, a financial evaluation can be conducted. 
Acknowledgment: This research is financially supported by the Ministry of Education, Science and Technological Development of the Republic of Serbia (Contract No. 451-03-9/2021-14/200109).

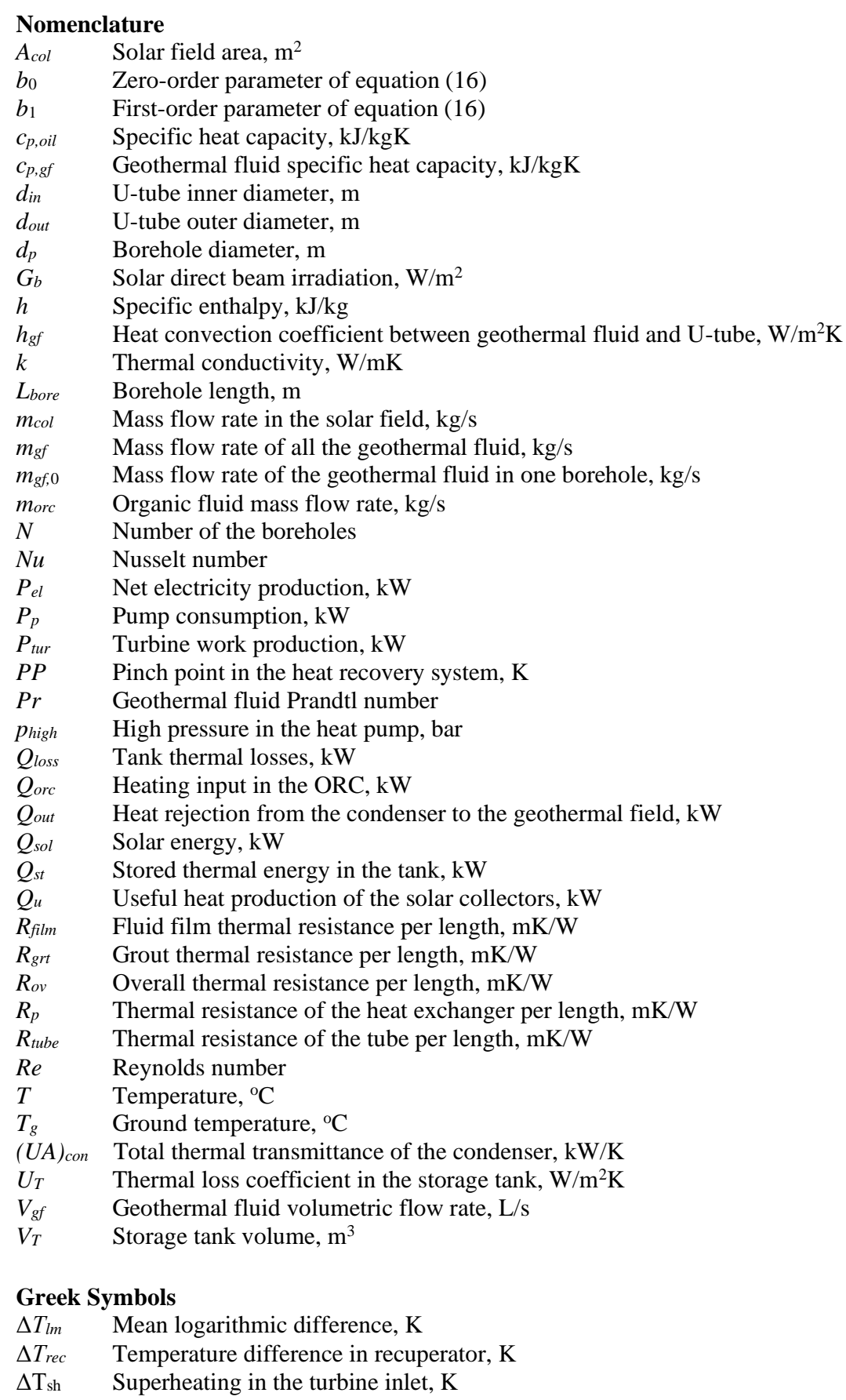




$\begin{array}{ll}\eta_{\text {col }} & \text { Solar collector thermal efficiency } \\ \eta_{e l} & \text { System electrical efficiency } \\ \eta_{i s} & \text { Isentropic efficiency of the turbine } \\ \eta_{\text {mg }} & \text { Electromechanical efficiency in generator } \\ \eta_{\text {motor }} & \text { Total efficiency of the motor that drives the pump } \\ \eta_{\text {orc }} & \text { Organic Rankine cycle thermodynamic efficiency } \\ \rho_{g f} & \text { Geothermal fluid density, } \mathrm{kg} / \mathrm{m}^{3}\end{array}$

\section{Subscripts and Superscripts}

$\begin{array}{ll}\text { am } & \text { Ambient } \\ \text { col } & \text { Collector } \\ \text { col,in } & \text { Collector inlet } \\ \text { col,out } & \text { Collector outlet } \\ \text { con } & \text { Condenser } \\ \text { con, in } & \text { Condenser inlet } \\ \text { con,out } & \text { Condenser outlet } \\ \text { gf } & \text { Geothermal fluid } \\ \text { gf, } m & \text { Mean geothermal fluid } \\ g r t & \text { Grout }\end{array}$

\section{Abbreviations}

ORC Organic Rankine cycle

HRS Heat recovery system

\section{REFERENCES}

1. Al-Rabeeah A.Y., Seres I., Farkas I., Recent improvements of the optical and thermal performance of the parabolic trough solar collector systems, Facta Univesitatis, Series: Mechanical Engineering 2021 (10.22190/FUME201106030A)

2. Rafiei A., Loni R., Mahadzir S.B., Najafi G., Pavlovic S., Bellos E., Solar desalination system with a focal point concentrator using different nanofluids, Applied Thermal Engineering 2020;174:115058

3. Said Z., Hachicha A.A., Aberoumand S., Yousef B.A.A., Sayed E.T., Bellos E., Recent advances on nanofluids for low to medium temperature solar collectors: energy, exergy, economic analysis and environmental impact, Progress in Energy and Combustion Science 2021;84:100898

4. Saravanan D., Wilson V., Kumarasamy S., Design and thermal performance of the solar biomass hybrid dryer for cashew drying, Facta Univesitatis, Series: Mechanical Engineering 2014:12(3); 277-288

5. Pereira J.S., Ribeiro J.B., Mendes R., Vaz G.C., André J.C., ORC based micro-cogeneration systems for residential application - A state of the art review and current challenges, Renewable and Sustainable Energy Reviews 2018;92:2018:728-743

6. Stefanovic V., Bojic M., Pavlovic S., Apostolovic N., A prototype receiver for medium temperature conversion of solar radiation to heat, Facta Univesitatis, Series: Mechanical Engineering 2011;10(1):37-49

7. Bellos E., Tzivanidis C., Alternative designs of parabolic trough solar collectors, Progress in Energy and Combustion Science 2019;71:81-117

8. Pavlović S., Vasiljević D., Stefanović V., Stamenković Z., Ayed S., Optical model and numerical simulation of the new offset type parabolic concentrator with two types of solar receivers, Facta Univesitatis, Series: Mechanical Engineering 2015;1(2):169-180

9. Loni R., Kasaeian A., Asli-Ardeh E.A., Ghobadian B., Le Roux W., Performance study of a solarassisted organic Rankine cycle using a dish-mounted rectangular-cavity tubular solar receiver, Applied Thermal Engineering 2016;108:1298-1309.

10. Loni R., Kasaeian A., Asli-Ardeh E.A., Ghobadian B., Optimizing the efficiency of a solar receiver with tubular cylindrical cavity for a solar-powered organic Rankine cycle, Energy 2016;112:1259-1272

11. Loni R., Kasaeian A., Mahian O., Sahin A., Thermodynamic analysis of an organic rankine cycle using a tubular solar cavity receiver, Energy Conversion and Management 2016;127:494-503 
12. Ozturk M., Dincer I., Thermodynamic analysis of a solar-based multi-generation system with hydrogen production, Applied Thermal Engineering 2013;51:1235-1244

13. Moradi M., Mehrpooya M., Optimal design and economic analysis of a hybrid solid oxide fuel cell and parabolic solar dish collector, combined cooling, heating and power (CCHP) system used for a large commercial tower, Energy 2017;130:530-543

14. Yilmaz F., Ozturk M., Selbas R., Energy and exergy performance assessment of a novel solar-based integrated system with hydrogen production, International Journal of Hydrogen Energy 2019;44(34): $18732-18743$

15. F-Chart Software, Engineering Equation Solver (EES), 2015. Available at: (http://www.fchart.com/ees)

16. Pavlovic S., Bellos E., Le Roux W.G., Stefanovic V., Tzivanidis C., Experimental investigation and parametric analysis of a solar thermal dish collector with spiral absorber, Applied Thermal Engineering 2017;121:126-135

17. Bellos E., Tzivanidis C., Investigation of a hybrid ORC driven by waste heat and solar energy, Energy Conversion and Management 2018;156:427-439

18. Stefanovic V.P., Pavlovic S.R., Bellos E., Tzivanidis C., A detailed parametric analysis of a solar dish collector, Sustainable Energy Technologies and Assessments 2018;25:99-110

19. Bellos E., Pavlovic S., Stefanovic V., Tzivanidis C., Nakomcic-Smaradgakis B.B., Parametric analysis and yearly performance of a trigeneration system driven by solar-dish collectors, International Journal of Energy Research 2019;43:1534- 1546

20. Bellos E., Tzivanidis C., Parametric analysis and optimization of a solar driven trigeneration system based on ORC and absorption heat pump, Journal of Cleaner Production 2017;161:493-509

21. Kavanaugh S., Rafferty K., Geothermal Heating and Cooling, Design of Ground-Source Heat Pump Systems, ASHRAE, Atlanta, 2014, ISBN 978-1-936504-85-5

22. Colburn A.P., A method of correlating forced convection heat-transfer data and a comparison with fluid friction, International Journal of Heat and Mass Transfer 1964:7(12):1359-1384

\section{NUMERIČKO ISTRAŽIVANJE ORGANSKOG RANKINOVOG CIKLUSA SPREGNUTOG SA SOLARNIM I GEOTERMALNIM POLJEM}

Cilj ovog rada je istraživanje organskog Rankinovog ciklusa (ORC) pogonjenog solarnom energijom za proizvodnju električne energije sa geotermalnim bunarom koji ima funkciju toplotnog ponora za ORC kondenzator. Ispitana jedinica kombinuje eksploataciju dva obnovljiva izvora energije. Solarno zračenje se utilizuje preko paraboličnih tanjirastih solarnih koncentratora sa spiralnim apsorberom, dok geotermalno polje uključuje vertikalne bušotine sa U-cevima. Sistem se parametarski istražuje razvijenim modelom u Engineering Equation Solver-u, a ispitivani parametri su nivo ozračenosti sunčevog zraka, ukupna toplotna provodljivost ORC kondenzatora, dužina bušotine, broj bušotina i srednja temperatura tla. Za podrazumevani scenario utvrđeno je da električna efikasnost sistema iznosi $21.45 \%$, termodinamička efikasnost ORC-a iznosi $35.99 \%$, a efikasnost solarnog polja $61.30 \%$. Staviše, utvrđeno je da je ispitivani sistem za $5.7 \%$ efikasniji od konvencionalnog sistema vazdušno hlađenog kondenzatora.

Ključne reči: parabolični tanjirasti solarni koncentrator, organski Rankinov ciklus, geotermalna energija, parametarska analiza, koncentrišući solarni termalni sistemi 